\title{
La aplicación del artículo 91 de la Constitución de Rionegro. Una herramienta constitucional para la solución de los conflictos armados*
}

\section{The application of article 91 from Rionegro's Constitution. A constitutional tool to solve armed conflicts}

SUMARIO

Introducción. I. Guerras y conflictos armados entre 1863 y 1886. II. Las declaratorias de turbado el orden público y de estado de guerra. III. Diarios oficiales que denotan la aplicación del derecho de gentes como una herramienta constitucional para regular y solucionar los conflictos armados. Reflexiones finales.

\section{RESUMEN}

El presente artículo pretende ilustrar cómo el derecho de gentes fue utilizado o aplicado como una herramienta constitucional para regular y dar solución a los conflictos armados ocurridos durante la vigencia de la Constitución de Rionegro de 1863 en los Estados Unidos de Colombia. Para ello, este trabajo se asienta en el análisis de fuentes directas de conocimiento como lo son los Diarios Oficiales de la época. Estos contienen la información pertinente y necesaria para ilustrar el objetivo de este trabajo.

* $\quad$ Recibido el 15 de diciembre de 2014, aprobado el 1 de abril de 2015.

Para citar el artículo: I. D. Otero SuÁRez. La aplicación del artículo 91 de la Constitución de Rionegro. Una herramienta constitucional para la solución de los conflictos armados. Revista Derecho del Estado n. ${ }^{\circ}$ 34, Universidad Externado de Colombia, enero-junio de 2015, pp. 203 235. DOI: 10.18601/01229893.n34.10

** Docente-investigador del Departamento de Derecho Constitucional de la Universidad Externado de Colombia. Abogado y candidato a magíster en Derecho Público por la misma Universidad.Contacto: ivan.otero@uexternado.edu.co 
PALABRAS CLAVE

Derecho de gentes, orden público, conflicto armado, aplicación, Diarios Oficiales.

ABSTRACT

This article pretends to explain how the law of nations was used as a constitutional tool to solve the armed conflicts between 1863 and 1886 in the United States of Colombia. To accomplish this but, the present work is based on direct sources of knowledge, like they are the Official Journal issued at this period. From them, we made an analysis and extracted the relevant information to illustrate the purpose of this investigation.

KEY WORDS

Law of nations, public order, armed conflict, application, Official Journal.

INTRODUCCIÓN

El 8 de mayo de 1863 se promulgó la Constitución de Rionegro. Por primera vez un texto constitucional en nuestro país decidió integrar el derecho de gentes a la legislación nacional, esto por medio de su artículo 91 que rezaba:

El Derecho de Gentes hace parte de la legislación nacional. Sus disposiciones regirán especialmente en los casos de guerra civil. En consecuencia, puede ponerse término a ésta por medio de tratados entre beligerantes, quienes deberán respetar las prácticas humanitarias de las naciones cristianas y civilizadas.

Cabe precisar que en sus inicios este derecho había sido entendido como el derecho internacional público. Sin embargo, con el transcurrir del tiempo y los avances en las instituciones jurídicas, su contenido se fue acotando en regular los asuntos de la guerra, hasta traducirse en el hoy llamado derecho internacional humanitario. No se pretende en este breve escrito desarrollar su concepto ni mostrar su evolución, por el contrario, se quiere ilustrar cómo este se aplicó como una herramienta constitucional para resolver los conflictos armados entre 1863 y 1886. A pesar de lo anterior, sí se considera necesario brindar una definición al respecto. Para ello acudiremos al concepto de derecho gentes construido por BELLo, que recoge en buena medida los planteamientos elaborados por la doctrina internacional, y a su vez se aplicó durante el siglo xix en Colombia. Según Bello, el ius gentium puede entenderse como: 
... la colección de las leyes o reglas generales de conducta que las naciones deben observar entre sí para su seguridad y bienestar común. Toda ley supone una autoridad de que emana. Como las naciones no dependen unas de otras, ni cada una de ellas del agregado de todas, las leyes a que se someten obrando colectivamente solo pueden serles dictadas por la razón, que a la luz de la experiencia, y consultando el bien común, las deduce del encadenamiento de causa y efectos que rige el universo moral ${ }^{1}$.

Entre los aspectos más destacados de la obra de BELlo que tienen que ver con la regulación de los conflictos armados y la guerra se referencian los siguientes:

Las mujeres, niños y ancianos, los heridos y enfermos, son enemigos que no oponen resistencia, y por consiguiente no hay derecho de quitarles la vida, ni de maltratarlos en sus personas mientras no toman las armas. Lo mismo se aplica a los ministros de altar y a todas las profesiones pacíficas. Una severa disciplina debe reprimir los actos de violencia a que se abandona la soldadesca desenfrenada en las plazas que se toman por asalto. Pero en nuestros días hemos visto demasiadas veces violada esta regla.

Después de un combate debe el vencedor cuidar de los heridos que el enemigo deja en el campo de batalla. Las leyes de la humanidad y del honor vedan matarlos o desnudarlos. Se ajustan a veces armisticios para enterrar a los muertos y transportar a los heridos. No es lícito matar a los prisioneros, sino en los casos extremos, cuando su conocida disposición a la resistencia, o el aparecimiento de una fuerza enemiga, que viene a liberarlos, hace imposible o peligrosa su guarda. Solo la más imperiosa necesidad pudiera justificar diferente conducta ${ }^{2}$.

Por último, sobre el cumplimiento de los tratados o convenios celebrados en la guerra agrega:

Porque no todo deber cesa, ni todos los vínculos de la humanidad se rompen entre las naciones que hacen la guerra; y bien lejos de suspenderse en ellas la obligación de guardar fe, nunca es más importante a los hombres; pues en el curso de la guerra hay mil ocasiones en que, para poner a raya sus furores y moderar

1 Andrés Bello. Principios de derecho de gentes. Citado por Francisco Barbosa. Del Derecho de Gentes al Derecho Internacional Humanitario en Colombia, 1821-1995: debate sobre una idea constitucional. Bogotá, Instituto de Estudios Constitucionales Carlos Restrepo Piedrahita, 2013, p. 35.

2 Andrés Bello. Obras Completas. Citado por Alejandro V alencia Villa. La humanización de la guerra: derecho internacional humanitario y conflicto armado en Colombia. Bogotá, Tercer Mundo Editores, 1991, pp. 31 y 32. 
las calamidades que acarrea, la salud de ambos beligerantes exige que traten y estipulen sobre varias materias ${ }^{3}$.

No sobra resaltar que antes de la adopción del artículo 91 constitucional existieron algunos antecedentes sobre la aplicación consuetudinaria del derecho de gentes en nuestro país. Varios autores coinciden en que el primero de ellos se dio el 26 de noviembre de $1820^{[4]}$. Tras la Batalla de Boyacá y de la insurrección de Riego en el año citado, el Libertador Simón BoLívar y el comandante de las tropas españolas PABLo Morillo suscribieron un tratado para regularizar la guerra. En él se regularon importantes elementos de este derecho tales como: las prácticas de los pueblos civilizados (art. 1), el respeto, asistencia y canje de los prisioneros de guerra (arts. 2, 3, 5, 6, 8, 9 y 10), la atención médica a los heridos en combate (art. 4), la prohibición de la pena capital (art. 7) y el entierro de los muertos (art. 12).

Por otro lado, BARBOSA también referencia que el juicio contra el irlandés RUPERT HAND en 1830 y el fusilamiento del hermano del general José María Córdova en 1841 constituyeron aplicaciones consuetudinarias. El primer caso tuvo lugar durante el juicio contra Hand por el homicidio de José MARía Córdova. En esa oportunidad el Tribunal de Apelaciones del Distrito de Cartagena expresó que el asesinato cometido por Hand había sido contrario al derecho de gentes por no dar cuartel a los enemigos rendidos ${ }^{5}$. En el segundo, "el 7 de julio de 1841, el general Tomás Cipriano de Mosquera ordenó fusilar al hermano del general José MARía CóRDOVA y otros prisioneros" por tener ellos la posibilidad de escapar o huir. Para justificar ese fusilamiento, el general MosQuera cita a la doctrina internacional del derecho de gentes, fundamentalmente la de VATTEL y la de BELLO ${ }^{6}$.

Por su parte, SALVADOR CAMACHO RoldÁn trae tres ejemplos significativos que reflejan la necesidad de tener una norma clara y completa para regular todo lo atinente al derecho de gentes en el país. Esto último porque en ocasiones no era claro cómo debía interpretarse o aplicarse el mismo ${ }^{7}$.

El primer ejemplo se refiere a 1842 cuando el magistrado del Tribunal de Cundinamarca, José María Latorre Uribe, “ante quien pendía una causa contra un número considerable de prisioneros hechos en el combate de La Culebrera, condenados a muerte en primera instancia, había declarado que como a prisioneros en guerra civil no podía imponérseles esa ni ninguna otra pena, y que apenas había derecho para privarlos de su libertad hasta la

\footnotetext{
Ibíd.,p. 32.

Barbosa. Ob. cit., p. 43 a 47 y Valencia Villa. Ob. cit., pp. 25 a 30.

Ibíd., pp. 47 y 48.

Ibíd., pp. 49 y 50.

7 Salvador Camacho Roldán. Memorias de Salvador Camacho Roldán. Bogotá, Bedout,
} 1923 , pp. 303 a 304. 
cesación de la guerra"». Cuenta CAMACHO Roldán que esa sentencia causó gran escándalo y que al juez que la dictó lo destituyeron de su cargo y fue condenado a tres o más años de presidio que efectivamente cumplió.

El segundo ejemplo se refiere a 1844, cuando Simón SiLva, capitán que había servido a órdenes de un caudillo indígena llamado Ibito, asesinó por mandato de este a un alcalde del gobierno legítimo. Cuenta el autor que la insurrección de Ibito solo pudo terminar cuando se celebró una amnistía e indulto en su favor y en el de todos aquellos que le habían servido. A pesar de esto Silva fue procesado y en primera instancia condenado a muerte por el delito de asesinato.

El tercer y último ejemplo que trae el autor es más reciente que los anteriores: se trata de la guerra civil que ganaron los liberales y que dio lugar a la Convención y posterior Constitución de Rionegro. Cuenta que entre 1860 y 1863 el Gobierno Nacional se había rehusado a todo tipo de pacto con los revolucionarios alegando que las leyes existentes no lo facultaban para hacerlo, sino únicamente para castigarlos y restablecer el orden. De esta manera los conflictos armados presentados en aquella época hubiesen podido ser resueltos por algún medio pacífico.

Respecto a lo anterior, VALENCIA Villa indica que la inclusión del derecho de gentes en la Constitución de 1863 se debió a "el manejo que de la guerra de 1860 y 1861 hizo el presidente Ospina RodríGuez" . Asimismo, esta posición fue soportada por varios autores del siglo XIX ${ }^{10}$.

Hechas las anteriores precisiones, aquí se pretende ilustrar cómo fue utilizado o aplicado el artículo 91 de la Constitución de Rionegro para dar solución a los conflictos armados entre 1863 y 1886. Para ello, este trabajo se fundamenta en fuentes directas de conocimiento, como lo son los Diarios Oficiales de la época. De la totalidad de los diarios expedidos durante la vigencia de la Constitución de 1863 y para efectos de este artículo, hemos seleccionado 23 que muestran correctamente la forma como el derecho de gentes fue utilizado para la finalidad propuesta ${ }^{11}$. En la medida en que este trabajo se fundamenta en fuentes históricas, la mayor parte de las reflexiones y análisis aquí planteados se realizan con base en la información encontrada en los mencionados Diarios y no en fuentes doctrinales (indirectas).

$8 \quad$ Ibíd.

9 Valencia Villa. Ob. cit., p. 33.

10 Justo Arosemena. Constitución de los Estados Unidos de Colombia. Y Rafael Rocha. La verdadera y la falsa democracia. Citado por ValenCIA Villa. Ob. cit., p. 33.

11 Llave de lectura: No se hace la reproducción literal de los Diarios Oficiales aquí referenciados. Para efectos prácticos y didácticos, se hace una pequeña reseña de lo sucedido en determinado momento histórico y se cita su fuente. En ocasiones se transcriben apartes de los Diarios por su importancia o pertinencia. Por último, no sobra agregar que el criterio de selección de los Diarios fue que ellos permitieran dilucidar cómo se utilizó el artículo 91 constitucional para dar solución a los conflictos armados. 
Durante la vigencia de la Constitución de Rionegro existieron fundamentalmente dos grandes guerras civiles de carácter nacional: la de 1876-1877 y la de 1884-1885. Como se mostrará enseguida, en ellas se dio aplicación al artículo 91 constitucional que incorporó el derecho de gentes a la legislación nacional.

La primera de ellas se desarrolló en el contexto de la pérdida de las elecciones por parte de los conservadores en 1875 y el triunfo de los liberales ese mismo año, con la elección presidencial de AQUILEO PARRA para gobernar el país en el periodo 1876-1878. Los conservadores acusaban a los liberales, principalmente al presidente de la Unión, SANTIAGo Pérez, de parcialidad en las elecciones, por lo que en 1876 decidieron apelar a la guerra para hacer valer sus derechos ${ }^{12}$.

También es cierto que los conservadores estaban inconformes con los gobiernos liberales que se habían mantenido en el poder desde 1863 y que no los dejaban participar en el manejo general del país, especialmente en los temas de educación, prensa e Iglesia ${ }^{13}$.

La segunda gran guerra civil durante la vigencia de la Constitución de Rionegro tuvo lugar en 1885 y terminó por establecer un nuevo régimen constitucional con la Constitución de 1886. Su principal causa fueron las políticas del programa de "La Regeneración" del presidente Núñez, que había molestado a los liberales de ciertos Estados y que los llevó a oponerse por medios armados ${ }^{14}$.

Por otro lado, al interior de cada uno de los Estados se produjeron actos que no llegaron a convertirse en guerras civiles de carácter nacional, pero que por su importancia en la alteración o perturbación del orden público interno y la posibilidad de que sí llegasen a serlo, ameritaron la aplicación del derecho de gentes (art. 91 de la Constitución) para restablecer la tranquilidad y el orden en la Unión. Estos actos fueron: levantamientos y manifestaciones armadas, rebeliones, insurrecciones, toma de plazas públicas, y todo tipo de actos que pretendieron o intentaron desconocer al gobierno estatal de turno, derrocar el régimen constitucional vigente o simplemente oponerse al gobierno nacional elegido.

Es necesario precisar que el derecho de gentes como herramienta constitucional para solucionar los conflictos armados no solo se aplicó en las guerras civiles y extranjeras, sino también en aquellas perturbaciones del

12 Antonio José Rivadeneira. Historia Constitucional de Colombia 1510-1978. Bogotá, Editorial Horizontes, 1978, p. 134.

13 Tomado de Biblioteca Luis Ángel Arango y su red de bibliotecas. Guerra civil de 1876. En: [http://www.banrepcultural.org/blaa/archivos/guerra-civil-1876].

14 Rivadeneira. Ob. cit., pp. 134 y 135. 
orden público interno que podían poner en peligro la paz y tranquilidad de la Unión, o, como ya se expresó, a actos que pudieran terminar en guerras civiles a discrecionalidad de los gobernantes de turno. Así lo relató, según Restrepo Piedrahita, Don Lorenzo María Lleras al hablar de las motivaciones que inspiraron la inclusión del artículo 91 de la Constitución Nacional en aquellos días de la Convención de Rionegro: "tratábase, decimos, de acordar algunas disposiciones de prudencia que diesen seguridad al país, y facilitasen la defensa del Gobierno general y los gobiernos de los Estados, en los casos, muy probables por desgracia, de invasiones extranjeras o de perturbaciones internas de la paz"15.

Pues bien, en el contexto anterior es necesario establecer que en la Constitución de 1863 no se encontraba un capítulo o sección, propiamente dicho, que regulara los estados de guerra exterior, emergencia y conmoción interior, como existe hoy día en la Constitución de 1991; o, en su defecto, uno donde se establecieran las disposiciones normativas aplicables a las alteraciones del orden público o a la guerra ${ }^{16}$. Sin embargo, sí existían ciertas disposiciones en la Constitución de 1863 y en leyes, que fundamentaban un régimen de excepción parecido al que tenemos en la actualidad y por medio del cual se aplicó el derecho de gentes. Ellas se encontraban dispersas en Constitución y en diferentes leyes nacionales. Las que a continuación se referencian son aquellas que pudieron constatarse en los Diarios Oficiales consultados y analizados.

En lo que respecta a las constitucionales, estas se referían principalmente a los principios y bases de la Unión, la garantía de los derechos individuales, que por mandato constitucional podían limitarse en tiempos de guerra o perturbaciones del orden público, las competencias y atribuciones del Presidente de la República con relación a la guerra y el orden público, la sección de condiciones generales de la Unión y el capítulo de disposiciones varias ${ }^{17}$.

15 Carlos Restrepo Piedrahita. Documentos para la historia del constitucionalismo colombiano No. 4. Bogotá, Universidad Externado de Colombia, 2003, pp. 344 y 345.

16 A diferencia de esto, en las Constituciones de los Estados sí se reguló la perturbación del orden público. "La reglamentación del ejercicio de las facultades para el tratamiento de las alteraciones del orden público tuvo matices diferenciados en diversos estados. En algunas constituciones se mencionaron explícitamente facultades. En otras, el dictamen del Consejo de Estado o de Gobierno era obligatorio para el ejecutivo": Restrepo Piedrahita. Ob. cit., p. 209.

17 "Cap. I. La nación. Artículo 2. Los dichos Estados se obligan a auxiliarse y defenderse mutuamente contra toda violencia que dañe la soberanía de la Unión, o la de los Estados. Capítulo II. Bases de la Unión. Sección I. Derechos y deberes de los Estados. Artículo 8. En obsequio de la integridad nacional, de la marcha expedita de la Unión y de las relaciones pacíficas entre los Estados, estos se comprometen: 1. A organizarse conforme a los principios del Gobierno popular, electivo, representativo, alternativo y responsable; 2 . A no enajenar a potencia extranjera parte alguna de su territorio; 3 . A no restringir con impuestos, ni de otro modo, la navegación de los ríos y demás aguas navegables que no hayan exigido canalización artificial; 4. A no gravar con impuestos, antes de haberse ofrecido al consumo, los objetos que sean ya materia de 
impuestos nacionales, aun cuando se hayan declarado libres de los derechos de importación; ni los productos destinados a la exportación, cuya libertad mantendrá el Gobierno general; 5. A no imponer contribuciones sobre los objetos que transiten por el Estado, sin destinarse a su propio consumo; 6 . A no imponer deberes a los empleados nacionales, sino en su calidad de miembros del Estado, y en cuanto esos deberes no sean incompatibles con el servicio público nacional; 7. A no gravar con impuestos los productos y propiedades de la Unión Colombiana; 8. A deferir y someterse a la decisión del Gobierno general en todas las controversias que se susciten entre dos o más Estados, cuando no puedan avenirse pacíficamente, sin que en ningún caso, ni por ningún motivo, pueda un Estado declarar ni hacer la guerra a otro Estado; y, 9. A guardar estricta neutralidad en las contiendas que lleguen a suscitarse entre los habitantes y el Gobierno de otro Estado. Artículo 13. No se permitirá en ninguno de los Estados de la Unión, enganches o levas que tengan, o puedan tener, por objeto atacar la libertad, la independencia o perturbar el orden público de otro Estado o de otra Nación. Sección II. Garantía de los derechos individuales. Artículo 15. Es base esencial e invariable de la Unión entre los Estados, el reconocimiento y la garantía por parte del Gobierno general y de los Gobiernos de todos y cada uno de los Estados, de los derechos individuales que pertenecen a los habitantes y transeúntes en los Estados Unidos de Colombia, a saber: 1. La inviolabilidad de la vida humana; en virtud de lo cual el Gobierno general y el de los Estados se comprometen a no decretar en sus leyes la pena de muerte; 2 . No ser condenados a pena corporal por más de diez años; 3. La libertad individual; que no tiene más límites que la libertad de otro individuo; es decir, la facultad de hacer u omitir todo aquello de cuya ejecución u omisión no resulte daño a otro individuo o a la comunidad; 4. La seguridad personal; de manera que no sea atacada impunemente por otro individuo o por la autoridad pública: ni ser presos o detenidos, sino por motivo criminal o por pena correccional: ni juzgados por comisiones o tribunales extraordinarios: ni penados sin ser oídos y vencidos en juicio; y todo esto en virtud de leyes preexistentes; 5. La propiedad; no pudiendo ser privados de ella, sino por pena o contribución general, con arreglo a las leyes, o cuando así lo exija algún grave motivo de necesidad pública, judicialmente declarado y previa indemnización. En caso de guerra la indemnización puede no ser previa, y la necesidad de la expropiación puede ser declarada por autoridades que no sean del orden judicial. Lo dispuesto en este inciso no autoriza para imponer pena de confiscación en ningún caso; 6 . La libertad absoluta de imprenta y de circulación de los impresos, así nacionales como extranjeros; 7. La libertad de expresar sus pensamientos de palabra o por escrito sin limitación alguna; 8. La libertad de viajar en el territorio de los Estados Unidos, y de salir de él, sin necesidad de pasaporte ni permiso de ninguna autoridad en tiempo de paz, siempre que la autoridad judicial no haya decretado el arraigo del individuo. En tiempo de guerra, el Gobierno podrá exigir pasaporte a los individuos que viajen por los lugares que sean teatro de operaciones militares; 9 . La libertad de ejercer toda industria y de trabajar sin usurpar la industria de otro, cuya propiedad hayan garantizado temporalmente las leyes a los autores de inventos útiles, ni las que se reserven la Unión o los Estados como arbitrios rentísticos; y sin embarazar las vías de comunicación, ni atacar la seguridad ni la salubridad; 10. La igualdad; y en consecuencia, no es lícito conceder privilegios o distinciones legales, que cedan en puro favor o beneficio de los agraciados; ni imponer obligaciones especiales que hagan a los individuos a ellas sujetos de peor condición que los demás; 11. La libertad de dar o recibir la instrucción que a bien tengan, en los establecimientos que no sean costeados con fondos públicos; 12. El derecho de obtener pronta resolución en las peticiones que por escrito dirijan a las corporaciones, autoridades o funcionarios públicos, sobre cualquier asunto de interés general o particular; 13 . La inviolabilidad del domicilio y de los escritos privados, de manera que aquel no podrá ser allanado, ni los escritos interceptados o registrados, sino por la autoridad competente, para los efectos y con las formalidades que determine la ley; 14. La libertad de asociarse sin armas; 15. La libertad de tener armas y municiones, y de hacer el comercio de ellas en tiempo de paz; 16. La profesión libre, pública o privada, de cualquier religión; con tal que no se ejecuten hechos incompatibles con la soberanía nacional, o que tengan por objeto turbar la paz pública. Sección 
En cuanto a las disposiciones legales, se pudo encontrar en los Diarios Oficiales principalmente las siguientes: la Ley 13 de 1863, que en su artículo 1. dispuso que era "deber de los presidentes de los Estados Federales declarar la situación de guerra cuando el Gobierno General haya declarado el país en dicha situación”. Y, a su vez, el libro IV del Código Militar de 1881. La importancia de este Código Militar se debió a que en su libro IV se encontraban disposiciones referentes a la aplicación del derecho de gentes. De esta manera, se regularon las conductas y acciones de los cuerpos militares en combates, operaciones y guerras, debiendo estar ajustadas, precisamente, a los postulados de este derecho.

Las anteriores disposiciones se materializaban o se llevaban a la práctica, como se podrá apreciar en los Diarios Oficiales aquí señalados, por medio de dos figuras distintas que aún hoy utilizamos, pero que para la época (1863-1886) a veces eran llevadas a la práctica como análogas aun sin estar contempladas formalmente en la propia Constitución. La primera de ellas se refiere a la "declaratoria de turbado el orden público", la segunda, a la declaratoria de "estado de guerra". Estas se explican a continuación; bajo las mismas se observaba la aplicación del derecho de gentes.

También cabe añadir que cuando el Presidente de la Unión declaraba turbado el orden público o el estado de guerra en todo el país o en algún Estado en particular, dicha declaratoria se fundamentaba principalmente en los artículos constitucionales $8,13,15,26,66$ y 91, y en las disposiciones legales de la ley 13 de 1863 y el libro IV del Código Militar de 1881. Cuando lo hacía directamente el Presidente de determinado Estado, las normas a invocar eran las de la propia Constitución de ese Estado, en particular la que regulaba el derecho de gentes. Frente a esta última idea, cabe simplemente

IV. Condiciones generales. Artículo 19. El Gobierno de los Estados Unidos no podrá declarar ni hacer la guerra a los Estados sin expresa autorización del Congreso, y sin haber agotado antes todos los medios de conciliación que la paz nacional y la conveniencia pública exijan. Artículo 26. La fuerza pública de los Estados Unidos se divide en naval y terrestre a cargo de la Unión, y se compondrá también de la milicia nacional que organicen los Estados según sus leyes. La fuerza a cargo de la Unión se formará con individuos voluntarios, o por un contingente proporcional que dará cada Estado, llamando al servicio a los ciudadanos que deban prestarlo, conforme a las leyes del Estado. En caso de guerra se podrá aumentar el contingente con los cuerpos de la milicia nacional, hasta el número de hombres necesarios para llenar el contingente que pida el Gobierno general. Artículo 66. Son atribuciones del Presidente de la Unión: (...) 5. Declarar la guerra cuando la haya decretado el Congreso, y dirigir la defensa del país en caso de invasión extranjera, pudiendo llamar al servicio activo, si fuere necesario, la milicia de los Estados; 6 . Dirigir las operaciones de la guerra como Jefe Superior de los Ejércitos y de la Marina de la Unión; 11. Impedir cualquiera agresión armada de un Estado de la Unión contra otro de la misma, o contra una Nación extranjera; 19. Velar por la conservación del orden general; Capítulo. XI. Disposiciones Varias. Artículo 91. El Derecho de gentes hace parte de la Legislación nacional. Sus disposiciones regirán especialmente en los casos de guerra civil. En consecuencia, puede ponerse término a ésta por medio de Tratados entre los beligerantes, quienes deberán respetar las prácticas humanitarias de las naciones cristianas y civilizadas". 
precisar que, organizados los Estados Unidos de Colombia en un sistema federal, las asambleas constituyentes de los Estados miembros se ocuparon de regular lo concerniente a la inclusión del derecho de gentes en sus respectivas constituciones ${ }^{18}$.

\section{LAS DECLARATORIAS DE TURBADO EL ORDEN PÚBLICO Y DE ESTADO DE GUERRA}

Respecto a la declaratoria de turbado de orden público, varios motivos o circunstancias llevaban a adoptarla en un Estado de la Unión o en todo el territorio nacional. A pesar de que la Constitución no definió cómo debía entenderse la turbación del orden público, se pudo interpretar que generalmente comportaba una grave alteración de la estabilidad política, institucional y de la tranquilidad de los Estados y de la Unión misma, como también circunstancias que pusieran en riesgo la seguridad y la convivencia de la población. Por ejemplo: un grupo de rebeldes armados que ocupaban una plaza pública y gritaban arengas amenazantes contra el gobierno de turno poniendo en condición de zozobra a la población de ese Estado o de la Unión.

La declaratoria también se llevaba a cabo cuando tenían lugar levantamientos y manifestaciones armadas, rebeliones, insurrecciones, toma de plazas públicas, y todo tipo de actos que pretendieran o intentaran desconocer al gobierno estatal de turno, derrocar el régimen constitucional vigente o simplemente oponerse al gobierno nacional elegido, pero que aún no eran tan graves y generalizados como para declarar un estado de guerra.

De esta forma, cuando las anteriores situaciones de afectación del orden público se agravaban o se hacían permanentes por no poder controlarlas, se hacía necesario declarar el estado de guerra; pero también cuando la Nación necesitaba atacar o defenderse de una agresión armada por parte de otra nación, o cuando, no ocurriendo esto último, lo que se desataba era una guerra civil (enfrentamiento entre ciudadanos del mismo Estado o país).

Las consecuencias de estas declaratorias se basaban en que el Gobierno de la Unión o el de los Estados, dependiendo de quién las había realizado, tenían las facultades necesarias para detener las causas que habían ocasionado esa perturbación del orden o la guerra, y a su vez, para impedir su prolongación. Esto último por tratarse de una situación excepcional. Por eso se decía anteriormente que las normas constitucionales y legales citadas integraban o fundamentaban un régimen de excepción, ya que en virtud de ellas, por

18 Para efectos de este artículo no se analizará la regulación del derecho de gentes en las constituciones federales. Para profundizar sobre el tema cfr. CARlos Restrepo Piedrahita. Constituciones de la Primera República Liberal. 1855-1885, t. III. Constituciones Federales Antioquia-Bolívar. Bogotá, Universidad Externado de Colombia, 1985, p. 203. 
ejemplo, se podía limitar las garantías individuales, llamar al servicio militar a los ciudadanos, exigir contribuciones de guerra, etc.

Sin embargo, también se pudo analizar que estas facultades para contrarrestar las situaciones excepcionales no eran absolutas. Estas tenían esencialmente dos limitaciones: la primera de ellas, el respeto por la Constitución y las leyes, y la segunda, la observancia de las normas e instituciones que integraban el derecho de gentes, incorporadas a la legislación nacional por medio del artículo 91 de la Constitución.

III. DIARIOS OFICIALES QUE DENOTAN LA APLICACIÓN DEL DERECHO DE GENTES COMO UNA HERRAMIENTA CONSTITUCIONAL PARA REGULAR Y SOLUCIONAR LOS CONFLICTOS ARMADOS

En los Diarios Oficiales consultados y seleccionados por su relación con la aplicación del derecho de gentes como herramienta constitucional para dar solución a los conflictos armados, se encontraron una serie de medidas excepcionales que demuestran la aplicación de este derecho y que se tomaron en virtud de las declaratorias de turbado el orden público y de estado de guerra. Ellas pretendieron restablecer el orden público turbado en la Nación o en los Estados, hacer la paz cuando se estaba en guerra, y humanizar los conflictos armados y las guerras que se presentaron entre 1863 y 1886. Dichas medidas se fundamentaban principalmente en los ya citados artículos $8,13,15,26$, 66 y 91 constitucionales, en el artículo $1 .^{\circ}$ de la Ley 13 de 1863 y en el libro IV del Código Militar de 1881, cuando lo hacía el Presidente de la Unión; y cuando lo hacía el de cada Estado, en las normas de sus propias constituciones, en especial en la disposición que regulaba el derecho de gentes. Las mencionadas medidas excepcionales fueron las siguientes.

A. Realizar negociaciones de paz con los beligerantes que hacían la guerra. Asimismo, la posterior celebración de tratados y acuerdos de paz entre los rebeldes y el Gobierno de la Unión o el de los Estados.

1. Bogotá, sábado 6 de febrero de 1864.D.O.n. ${ }^{\circ}$ 145. Tratado de Paz con la República del Ecuador. Tras los enfrentamientos que se venían registrando a finales de 1863 con el país vecino del Ecuador, principalmente porque ese país estaba haciendo invadir el territorio nacional por partidas de traidores asilados en aquella Nación, el presidente Mosquera consideró que esas situaciones se habían normalizado. Los enfrentamientos se concentraron en la batalla de "Cuaspud", donde se obtuvo la victoria para las tropas colombianas sin mayores novedades. Por eso, para ratificar la paz y el orden, se firmaron dos tratados entre Colombia y ese país. El primero de ellos fue un tratado de paz, y el segundo, un tratado adicional de cooperación, amistad, comercio y navegación. 
Existió aquí una forma pacífica de solucionar los conflictos armados. En aquella ocasión, por medio de los tratados de paz y de cooperación, amistad y comercio. En una alocución presidencial posterior, MOSQUERA agradeció a la Convención de Rionegro por haber incluido el artículo 91 de la Constitución Nacional sobre derecho de gentes, ya que ello no solo había permitido hacer la paz, sino también ratificarla. Para ese entonces expresó:

Honra i gloria debemos a la Convención Nacional de Rionegro que supo conciliar el ejercicio del poder ejecutivo con la dirección de la guerra; i prever al mismo tiempo el desempeño constitucional en los demás ramos administrativos en la capital de la República para mantener la armonía i la integridad nacional. Tales disposiciones i la del artículo 91 de la Constitución declarando como lei del país el derecho de jentes, me han permitido, no solamente hacer la paz, sino también ratificarla.

2. Bogotá, lunes 29 de febrero de 1864.D.O..$^{\circ} 149$. Mensaje del Presidente de los Estados Unidos de Colombia al Presidente del Senado. Este mensaje que el presidente Mosquera envió al presidente del Senado de la República tuvo que ver con los sucesos de enfrentamientos armados que habían ocurrido con el Ecuador a finales de 1863. Después de haber obtenido la victoria en la batalla de "Cuaspud" en aquel país, y haber firmado los tratados de paz, cooperación y amistad, Mosquera envió el texto del tratado de paz para que el Congreso lo conociera, de nuevo haciendo alusión expresa al artículo 91 de la Constitución Nacional:

Tengo el honor de poner en conocimiento del Congreso, por vuestro respetable conducto, el tratado de paz por el cual se terminó la guerra con el Ecuador, i que ratifiqué a virtud de las disposiciones del artículo 91 de la Constitución.

3. Bogotá, 30 de abril de 1864 D.O. n. ${ }^{\circ}$ 1. Circular de la Secretaría de lo Interior y de Relaciones Exteriores. La Circular en mención refleja que fue necesaria la aplicación del artículo 91 de la Constitución Nacional en tiempos de guerra, pero que una vez lograda la paz, esta norma se hizo innecesaria. Algo que denota el uso de forma excepcional del derecho de gentes. La circular se refería a las declaraciones de "estado de guerra" que hicieron varios Estados del país cuando hubo invasiones armadas no autorizadas por parte del Ecuador hacia los Estados Unidos de Colombia. En esta ocasión se hizo alusión explícita al derecho de gentes. Veamos.

Con motivo de la guerra que desgraciadamente tuvo que sostener el Gobierno jeneral a fines del año próximo pasado con la República del Ecuador, para rechazar la invasión del territorio de los Estados Unidos de Colombia, algunas porciones de dicho territorio fueron declaradas en estado de guerra, ordenándose, en con- 
secuencia, que en ellas se observara el derecho de Jentes, de conformidad con lo dispuesto en el art. 91 de la Constitución federal. Esta medida o providencia, arreglada a dicho artículo, i conveniente en los momentos en que se dictó, es hoy innecesaria habiéndose terminado gloriosamente la guerra con el Ecuador i firmándose la paz con aquella República nuestra vecina i hermana.

A su vez, en la anterior circular se ordenaba el restablecimiento de las garantías individuales (art. 15) que fueron limitadas en los estados de guerra. Allí se dijo:

... al anunciar a los Estados el Ciudadano Presidente de la Unión, como lo hace, con verdadera complacencia, la perfecta paz de que afortunadamente disfruta hoy la República, cree de su deber apresurarse a declarar que en todo el territorio de los Estados Unidos de Colombia impera en toda su plenitud i sin limitación alguna la Constitución Federal, haciendo mui especialmente esta declaratoria respecto del artículo 15 que garantiza los derechos individuales, los que se harán prácticamente efectivos a todos los habitantes i transeúntes en dicho territorio.

4. Bogotá, 11 de junio de 1864. D.O. n. ${ }^{\circ}$ 37. Secretaría de lo Interior y de Relaciones Exteriores. La paz con Antioquia. Después de enfrentamientos armados entre los Estados de Cauca y Antioquia, se logró la paz entre ellos. Tras estos sucesos, el secretario del Interior y de Relaciones Exteriores hizo una reflexión sobre el derecho de gentes y la importancia del mismo para mantener la paz. Allí señaló que a pesar de que algunos gobiernos han querido darle otro alcance o han abusado de esta norma, ella limita el poder y se dispuso para la protección de las garantías mismas que da la Constitución Nacional, no para vulnerarlas. Sería ilógico que tratando de protegerlas, la misma Constitución haya dispuesto de un medio para atacarlas; cosa diferente es que por excepción o en situaciones de guerra, solamente, esto pueda hacerse. En sus palabras dijo:

El art. 91, lejos de autorizar prácticas liberticidas o bárbaras, como se ha pretendido, es una declaración del más alto interés para facilitar los arreglos pacíficos, aún en medio de las más obstinadas guerras civiles, para evitar las cobardes persecuciones de los vencedores sobre los vencidos y para morigerar en todo sentido la guerra.

Después de estos pronunciamientos de un miembro del Gobierno General, se interpreta que oficialmente hay una postura acerca de la finalidad propia del derecho de gentes en esa época, y además que el mismo se constituía como una herramienta para garantizar la paz, el orden y la protección las garantías constitucionales. También, como un medio pacífico para solucionar los conflictos armados y humanizar la guerra. 
5. Bogotá, martes 12 de diciembre de 1865. D.O. n..$^{\circ}$ 507. Tratado de paz donde se puso término a la guerra en el Estado del Tolima. Este Diario informa que ante el hostigamiento de las fuerzas nacionales contra los rebeldes en el Estado del Tolima, estos últimos deciden celebrar un tratado de paz con el Gobierno para poner término a las contiendas armadas.

El anterior, es otro caso de la aplicación del derecho de gentes. Allí se puso término a un conflicto armado por medio de arreglos pacíficos, esto es, de tratados de paz. Veamos algunos artículos del mismo que regularon lo concerniente a la paz, la entrega de armas y el pago de expropiaciones:

Los infrascritos, Zoilo Cuéllar e Ignacio Umaña, debidamente autorizados, el primero por el jeneral en jefe del estado, ciudadano jeneral José Hilario López; i el segundo por el señor Eustaquio Caicedo, como jefe de los revolucionarios, previa la presentación de nuestros respectivos poderes i su correspondiente canje, hemos convenido, para dar término a la actual contienda, de una manera pacífica, en el siguiente

TRATADO:

Art. 1. Los caudillos de los revolucionarios que comanda el espresado señor Caicedo, i cuya designación se hará por el jeneral en jefe, pasándose la lista respectiva, saldrán del territorio del estado sin poder volver a él, antes de diez años, so pena de quedar sujetos a juicio i castigados por las leyes del estado, como perturbadores del orden público.

\section{$(\ldots)$}

Art. 4. Umaña se compromete a entregar, una vez aprobado el presente tratado, al teniente coronel Daniel Manrique, todas las armas propias i comunes a la guerra, sean de propiedad particular de los revolucionarios, de estraños, del gobierno nacional o del estado. Así mismo se compromete a entregar todas las municiones i demás elementos de guerra, igualmente que las caballerías que tuvieren en su campamento, escepto veinte.

Art. 5. Los caudillos de que habla el artículo 1. ${ }^{\circ}$ se comprometen de mancomún i solidariamente a pagar, dentro de un año, las espropiaciones que hubieren hecho en los pueblos en donde se han encontrado, una vez comprobadas por los interesados, de una manera legal, ante las autoridades judiciales del Estado.

Z. Cuéllar-Ignacio Umaña - Ratificado

Eustoguio Caicedo - Ratificado

El Jeneral en Jefe - José Hilario López 
Capitolio, noviembre 27 de 1865.

Aprobado, i dése cuenta el poder ejecutivo de la Unión.

El Presidente del Estado, Clímaco Iriarte.

El Secretario de Gobierno i Guerra, José A. Várgas.

6. Bogotá, viernes 23 de agosto de 1867. D.O.n..$^{\circ}$ 1.009. Convenio de paz en virtud del artículo 91 de la Constitución Nacional. Después del cambio de gobierno, esto es, de Mosquera a Santos, hubo ciertas fuerzas rebeldes que se opusieron a él. Lo anterior condujo a una serie de enfrentamientos armados a lo largo del país entre las tropas rebeldes y el nuevo gobierno nacional de Santos Acosta.

En este Diario Oficial se puede constatar cómo, tras la situación antes descrita, se suscribió un convenio de paz entre las pocas fuerzas rebeldes que aún quedaban, lideradas principalmente por Rudecindo López, y el Gobierno Nacional. Este último representado por Lucio Estrada, coronel de la Unión, comisionado especial por el poder ejecutivo nacional. De esta manera se quiso poner fin a la guerra en todo el territorio patrio. Esta vez también se invocó el artículo 91 de la Constitución Nacional sobre el derecho de gentes, estipulándose:

\section{CONVENIO DE PAZ}

Los infrascritos, a saber: Rudecindo López, Comandante jeneral de Marina i en Jefe de la segunda División de la Guardia Colombiana, por una parte; i por otra Lucio Estrada, Coronel de la Unión, comisionado especial por el Poder Ejecutivo nacional de la Unión colombiana, para el efecto de esta negociación, conforme a las credenciales que ha presentado i han sido halladas en debida forma; deseando que se ponga término a la guerra en todo el territorio colombiano por medios conciliatorios i civilizados, conforme a las prescripciones del artículo 91 de la Constitución nacional, hemos acordado un convenio de paz en los términos siguientes:

Artículo $1 .^{\circ}$ López por sí i a nombre de la División de su mando se somete a la autoridad del Gobierno a cuyo frente se halla hoy el ciudadano Jeneral Sántos Acosta. Aceptando como cumplido el hecho de que surjió el cambio de Gobierno el veintitrés de mayo último.

Artículo 2. ${ }^{\circ}$ La División seguirá inmediatamente para la capital de la Unión, a ponerse a las órdenes del Poder Ejecutivo nacional, escepto el batallón "Rejenerador", que quedará en el Estado Soberano de Bolívar bajo la inspección del Poder Ejecutivo del Estado, i a cargo de sus propios Jefes, hasta que tanto el mismo Gobierno nacional disponga otra cosa; las demás fuerzas organizadas en el Estado e incorporadas en la División, se mandarán disolver, salvo el caso de que el Gobierno de Bolívar quiera dejarla a su servicio i por cuenta del Estado. 
Artículo 3. Estrada ofrece i garantiza en nombre del Gobierno nacional i conforme a sus instituciones i facultades:

1. ${ }^{\circ}$ Que se reconocerán los actos del Jeneral López como Comandante jeneral de Marina i Segunda División, ejecutados hasta la fecha, como emanados de un poder lejitimo, pues es fuera de duda que era el que le dio instrucciones antes del 28 de abril último.

2. ${ }^{\circ}$ Que se solicitará por el Gobierno nacional del Estado Soberano del Magdalena una amnistía amplia para todos los habitantes de dicho Estado, por la parte que hayan tomado sirviendo en la división contra el Gobierno magdalenense, debiendo garantizarles el poder volver a sus domicilios i gozar en ellos de la plenitud de las garantías constitucionales;

3. ${ }^{\circ}$ Que se reconocerán en sus grados i empleos a los jefes, oficiales i tropa colocados en la División, sin que pueda privárseles de ellos sino por pena, previo juicio, conforme a las leyes i ordenanzas de la materia.

En virtud de los espuesto firmamos dos de un tenor en Cartajena, a diez i seis de julio de mil ochocientos sesenta i siete

Lucio Estrada y R. López

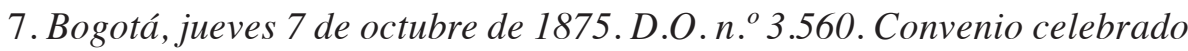
entre el Gobierno de la Unión y el Estado de Bolívar. Luego de tres meses de conflictos armados en el país, dadas las revoluciones que se habían iniciado en Panamá y Bolívar, este último Estado decidió derogar todos los decretos que declararon turbado el orden público y el estado de guerra en el mismo con la finalidad de obtener la paz. Posteriormente puso término a las contiendas armadas por medio de la celebración de un convenio de paz con el Gobierno de la Unión. Para esto último no se invocó el artículo 91 de la Constitución Nacional, pero es de conocimiento que el mismo brinda la posibilidad de poner término a la guerra por medio de tratados o convenios. En el citado convenio de paz se dijo:

\section{$(\ldots)$}

Art. 1. Derógase el decreto número 117, de 19 de julio último por el cual se declaró amenazada la soberanía del Estado, i en consecuencia se mandó a elevar el pie de fuerza pública.

Art. 2. Deróganse así mismo todos los decretos, resoluciones i ódenes espedidos en cumplimiento del referido decreto número 117. 
Art. 3. Dénse las órdenes del caso para que sean desarmados i devueltos los vapores a sus respectivos dueños, bajo inventario; para devolver las propiedades nacionales i de particulares que hayan sido tomadas; para el licenciamiento de la fuerza pública en servicio, dejando solamente la ordenada por la lei para el tiempo de paz; para suspender las ódenes que se habían espedido para aumentar la milicia en servicio; i todas las demás que sean necesarias para que el Estado quede en completa paz.

Dado en Cartajena, a 9 de septiembre de 1875.

8. Bogotá, jueves 4 de enero de 1877. D.O. n. ${ }^{\circ}$ 3.867. Negociaciones de paz con Antioquia. En el marco de la guerra civil que inició a mediados de 1876 , y luego de duras batallas en ese mismo año entre conservadores y liberales, el Gobierno de la Unión entró en negociaciones de paz con el Gobierno de Antioquia. Posterior a ello, uno de los jefes militares de este Estado decidió romper estas negociaciones y entrar en conflicto armado nuevamente. A pesar de ello, el Gobierno de la Unión decidió sacar a la luz pública y dar a conocer todos los documentos relacionados con las negociaciones de paz con el Gobierno antioqueño, las cuales evidenciaban la firme intención del Gobierno General por establecer la paz y no por continuar la guerra. Estas negociaciones de paz eran fruto de la aplicación de las normas del derecho de gentes en las guerras civiles, pretendiéndose poner término a las mismas por medio de tratados entre beligerantes. Fundamentalmente se establecieron los siguientes puntos en dichas negociaciones fracasadas:

1. Restablecimiento de las relaciones oficiales entre el Gobierno General y el de Antioquia;

2. Amnistía;

3. Indemnización por gastos de la guerra por un convenio especial;

4. Libertad de los prisioneros de guerra i presos políticos;

5. Insinuación de que se estipulara un convenio de paz entre los beligerantes del Tolima;

6. Concentración de las armas del Gobierno de Antioquia en los parques del interior del Estado, donde quedarían a disposición del Gobierno federal para el sostenimiento de las instituciones, como en los demás Estados de la Unión, y

7. Ratificación del Convenio y demás formalidades para su aprobación. 
9. Bogotá, jueves 8 de marzo de 1877. D.O.n..$^{\circ}$ 3.889. Combate de La Don Juana. Luego del combate en "La Don Juana", cerca de Pamplona, Santander, donde los liberales obtuvieron la victoria sobre un ejército de 4.000 conservadores, dejando como saldo más de mil muertos, fuera de los heridos, los ejércitos liberales brindaron atención a los heridos, los curaron y luego los dejaron en libertad dándoles incluso un auxilio proporcional de dinero. Estas conductas reflejan que en Colombia, para el momento de esta guerra civil, los ejércitos aplicaban las normas y prácticas de las naciones civilizadas en tiempos de guerra, o en otras palabras, el derecho de gentes conocido en su época. En el Boletín Oficial n. ${ }^{\circ} 83$ se puede evidenciar:

El Jefe del Estado Mayor Jeneral del Ejército de Santander, Coronel Narciso Cadena, quedó con un cuerpo sobre el campo de "La Don Juana", i con varios ayudantes, para reconocerlo prolijamente, para hacer recojer los muertos i el armamento abandonado, i para atender a los heridos de una i otra parte. (...) Los prisioneros cojidos durante la noche del día 27 i en la mañana de 28 , fueron conducidos a Cúcuta por un cuerpo de mi División, i allí puestos en libertad de orden del señor Jeneral Camargo, dándoles a todos un ausilio proporcional en dinero.

10. Bogotá, miércoles 2 de julio de 1879.D.O.n. ${ }^{\circ}$ 4.452. Sobre declaración en peligro del orden público en el Estado del Tolima. Por el temor de que estallara una revolución en el Estado del Tolima, este decidió declarar en peligro el orden público. Sus motivos se debieron a que se tenía conocimiento fidedigno de que desde hacía ya varios meses en la ciudad de Bogotá se preparaba una revolución contra dicho Estado. Decía el decreto respectivo:

DECRETO NÚMERO 322

Por el cual se declara en peligro el orden público en el Estado

El presidente del Estado soberano del Tolima CONSIDERANDO:

1. Que es un hecho indudable que en la ciudad de Bogotá, se trama una revolución contra el orden público de este Estado;

2. Que por conductos fidedignos se sabe que varias partidas de jente armada han pasado ya de aquel a este Estado con el objeto de verificar el movimiento;

3. Que las cartas de los señores Didacio B. Delgado i Severiano Buendía, Jefes de la revolución, indican que esta se llevara a cabo inmediatamente;

4. Que el primero de estos Jefes partió ya de Bogotá con tal objeto. 
DECRETA

Art. 1. Declárese en peligro el orden público en el Estado.

Art. 2. Para subvenir a los gastos que la situación demande, se recaudará en el Estado una contribución igual al impuesto directo del presente año. La primera mitad de esta contribución se recaudará inmediatamente i la segunda cuando lo disponga el poder ejecutivo.

Art. 3. Desde el momento en que aparezca en el Estado la perturbación del orden, se cobrará, además, un impuesto de cuatro pesos por cada cabeza de ganado mayor que se mate para el consumo.

Art. 4. Los Recaudadores de Hacienda procederán a recaudar la contribución de que habla el artículo $2{ }^{\circ}$ ejecutivamente i sin dar lugar a indebidas demoras.

Dado en Neiva, a 12 de Julio de 1879.

Ignacio Manrique

De esta forma, se observa que era necesario declarar turbado o en peligro el orden público para poder tomar las medidas necesarias para contrarrestar una eventual revolución. A su vez, cabe recordar que cuando se declaraba turbado el orden público o el estado de guerra, se debía dar aplicación y la más estricta observancia a las normas e instituciones del derecho de gentes, que era el que regía en este tipo de casos.

B. La limitación de las garantías individuales que establecía el artículo 15 constitucional. Como ya se explicó, era la misma Constitución la que permitía dichas limitaciones en tiempos de guerra o bajo graves motivos de necesidad pública y de orden público. Lo anterior se concretó fundamentalmente en reclutar forzosamente para el ejército nacional a todas las personas entre 16 y 60 años que pudiesen empuñar las armas y combatir, decretar expropiaciones de armas pertenecientes a los ciudadanos, restringir la libre locomoción en determinados Estados que eran teatro de operaciones militares, prohibir la realización de manifestaciones políticas en las calles, y adelantar la expropiación de inmuebles rurales y urbanos sin indemnización previa.

11. Bogotá, domingo 1 de enero de 1865. D.O. n. ${ }^{\circ} 212$. Decreto de restablecimiento de las garantías después de turbado el orden público en Bolivar. En este decreto se ordenó el restablecimiento pleno de las garantías individuales constitucionales después de haber quedado limitadas, mas no desconocidas, al declararse turbado el orden público. Veamos: 
EL PRIMER DESIGNADO ENCARGADO DEL PODER EJECUTIVO DEL Estado Soberano de Bolívar, en uso de sus atribuciones i considerando:

1. Que nada puede restablecer tanto la confianza en el pueblo boliviano, que el goce completo i positivo de las garantías individuales aseguradas por la Constitución; 2. Que el gobierno cuenta, como debe contar, con el patriotismo de todos los bolivianos sin distinción de colores políticos, a fin de que cuanto antes quede restablecida la paz i tranquilidad en el Estado,

DECRETA

Art. 1. Restablézcase en toda su fuerza i vigor las garantías individuales.

Art. 2. Deróguese el decreto de 11 de noviembre último.

Comuníquese a los gobernadores para su cumplimiento.

Dado en Cartajena, a 11 de diciembre de 1864.

Benjamín Noguera

Respecto de lo anterior cabe hacer una pequeña precisión: cuando se declaraba turbado el orden público o se decretaba el estado de guerra, entraba en vigencia y aplicación el derecho de gentes del artículo 91 constitucional. Así lo estableció la propia Constitución Nacional en el mismo artículo. En ocasiones, como la que se cita en el Diario Oficial n. ${ }^{\circ} 212$ de 1865, las garantías individuales del artículo 15 constitucional se podían limitar con el fin de restablecer el orden público o hacer la paz, sin que esa limitación implicara el desconocimiento de las mismas. De esa forma, una vez que cesaran las situaciones de anormalidad, estas garantías individuales debían restablecerse.

El artículo 15 constitucional puede interpretarse en el sentido de que la libertad individual (num. 3) podía limitarse cuando se ejecutaran comportamientos que pudieran ser dañinos para la comunidad u otro individuo. Asimismo podía limitarse la seguridad personal (num. 4), cuando existiera un motivo criminal o pena correccional. Por otra parte, podía limitarse el derecho a la propiedad (num. 5) en virtud de una pena o contribución general o cuando así lo exigiera un grave motivo de necesidad pública, judicialmente declarado y previa indemnización. Pero ante el caso de una guerra, la indemnización no debía ser previa y la necesidad de la expropiación podía ser declarada por autoridades que no fueran del orden judicial.

En ese sentido, también encontraba limitaciones la libertad de locomoción (num. 8) o de viajar libremente por el territorio nacional. Esto último, exigiendo un pasaporte o permiso especial para desplazarse cuando había 
situación o estado de guerra en determinados territorios o escenarios de operaciones militares.

De igual forma, la libertad de ejercer toda industria y de trabajar (num.9) podía verse restringida cuando esta afectara la seguridad y la salubridad. Por otra parte, existía la libertad de asociación (num. 14), pero la misma estaba prohibida cuando en esa asociación se involucraban armas.

Existía libertad de armas y municiones, se podía hacer el comercio de ellas (num. 15), pero en tiempos de guerra esto quedaba totalmente prohibido.

Y por último, podía ejercerse libremente cualquier profesión (num. 16), pero se podía limitar si esto resultaba en contra de la soberanía nacional o tenía por objeto turbar la paz pública.

C. Otorgar amnistías e indultos a los rebeldes alzados en armas por los delitos políticos cometidos.

12. Bogotá, martes 14 de noviembre de 1865. D.O. n. ${ }^{\circ}$ 483. Aprobación de un convenio de paz y la posterior amnistía o indulto. El Presidente del Estado soberano del Tolima y el coronel Francisco Caicedo Jurado, jefe de las fuerzas armadas que obraban contra el gobierno de turno, decidieron poner término a las contiendas armadas de una manera pacífica a través de un convenio de paz. Después de haberlo firmado, el Gobierno del Tolima decidió otorgar una amnistía o indulto a los rebeldes protagonistas del conflicto. En el convenio se estipuló:

Caicedo por sí i a nombre de sus fuerzas, reconoce el gobierno de la Unión i del Estado, i se compromete a disolver su ejército sin pérdida de tiempo, pudiendo, en consecuencia, volver pacíficamente a sus casas los individuos de que este se compone. Se entregarán por Caicedo todas las armas i elementos de guerra de su ejército, inmediatamente después que el comisionado del gobierno para recibirlas se presente en el punto donde se hallen.

Por otra parte, en la amnistía se estableció:

Art. 1. Concédase amnistía plena por todos los errores políticos que hayan cometido los individuos que se han puesto en armas contra el gobierno.

Art. 2. Los individuos que, según el convenio celebrado con el señor Francisco Caicedo J., jefe de los revolucionarios, deben salir del territorio del estado, pierden el derecho a esta gracia el día que indebidamente dejen de cumplir tal condición.

Una forma de poner término a los conflictos armados era a través de tratados entre beligerantes. Así lo autorizaba expresamente el artículo 91 de la Constitución de Rionegro. Aquí observamos cómo el derecho de gentes, así 
no se haga mención expresa, sirvió para restablecer el orden que se había turbado, hacer la paz y otorgar una amnistía a los rebeldes.

13. Bogotá, miércoles 10 de enero de 1866. D.O. n. ${ }^{\circ}$ 532. Amnistía que concedió el Estado del Tolima a todos aquellos rebeldes que le hubieren hecho la guerra. Recordemos que en el Estado del Tolima un grupo de rebeldes se había levantado contra el gobierno y el orden constitucional vigente. Después de someterlos, el 14 de noviembre de 1865 el Presidente del Estado soberano del Tolima y el coronel Francisco Caicedo Jurado, jefe de las fuerzas armadas que obraban contra el gobierno de turno, decidieron poner término a las contiendas armadas de una manera pacífica a través de un convenio de paz. Después de haberlo firmado, el Gobierno del Tolima decidió conceder una amnistía o indulto a los rebeldes protagonistas del conflicto.

Sin embargo, en este Diario Oficial del 10 de enero de 1866 se informa que el mismo Estado decidió conceder otra amnistía, esta vez una plena, por errores políticos, a todos aquellos que por cualquier motivo le hubieren hecho la guerra. Es decir, no solamente para el grupo de rebeldes inicial que se había levantado contra el gobierno de turno, sino para todos lo que hubieran hecho la guerra al Estado en general. Dicha amnistía plena implicó que todas las personas desterradas o confinadas de ese territorio pudieran volver a él. A su vez, que todos aquellos que se encontraran bajo prisión o pérdida de libertad pudieran recobrarla. Estas leyes de amnistía e indulto fueron un excelente medio, y de gran utilización, para hacer la paz y terminar los conflictos en esta época. A su vez, se constituyen como aplicaciones del derecho de gentes para hacer la paz y humanizar la guerra.

14. Bogotá, miércoles 31 de enero de 1866. D.O. n. 550. Amnistía que concedió el Estado de Cauca a todos aquellos rebeldes que le hubieren hecho la guerra. Tras varios enfrentamientos armados en el Estado de Cauca, se declaró turbado el orden público. En este Diario Oficial del 31 de enero de 1866 se informa que después de haber controlado la situación de guerra y declarado la paz en todo el Estado, el presidente del mismo, Eliseo Payán, concedió una amplia amnistía a los revolucionarios penados por el fallo del 25 de noviembre de 1865 emitido por el consejo de guerra. La amnistía estipuló:

Art. 1. Concedo amplia amnistía a los revolucionarios penados por el fallo del consejo de guerra, de 25 de noviembre de 1865. En consecuencia, pueden volver libremente a los lugares de su residencia o a los puntos del territorio del estado que tengan por convenientes; i no se les exijirá la multa que se les impuso.

Estas leyes de amnistía e indulto fueron un excelente medio, y de gran utilización, para hacer la paz y terminar los conflictos en esta época. A su vez, se constituyen como aplicaciones del derecho de gentes para hacer la paz y humanizar la guerra. 
15. Bogotá, jueves 2 de enero de 1873.D.O.n..$^{\circ}$ 2.740. Amnistía e indulto en el Estado de Cauca. Un grupo rebelde en el Estado de Cauca, dirigido por Rafael y Manuel de Guzmán, fue promoviendo, por medios armados, la separación de los municipios de Barbacoas, Obando, Pasto y Túquerres para exigir o con la pretensión de unir los mismos y formar un décimo Estado en el país. El gobierno del Estado de Cauca decidió entonces, como medida de paz, conceder una amnistía e indulto a los rebeldes, con la finalidad de que estos se reincorporaran a la vida civil y que se hiciera la paz. Lo anterior se llevó a cabo en virtud expresa del derecho de gentes. Por otra parte, esta amnistía estipuló un término para los alzados en armas que se quisieran beneficiar e hizo una excepción para que los cabecillas de los rebeldes se pudieran acoger a la misma. Así se dispuso en el artículo 1 de la amnistía:

Art. 1. Se concede amplio indulto i amnistía a todos los ciudadanos que separándose de las filas revolucionarias, se presenten dentro del término de diez días, contados desde la fecha en que se publique este decreto en la capital de cada municipio, ante los Jefes municipales de Barbacoas, Obando, Pasto i Túquerres, i entregando las armas que cada cual posea en la rebelión, sin que nunca se les pueda hacer cargo por los delitos i faltas en que han incurrido.

Parágrafo: quedan exceptuados de esta gracia, i deberán responder de su conducta, los cabecillas Rafael de Guzmán (padre) i Manuel de Guzmán, i los promovedores de la rebelión por miras eleccionarias.

16. Bogotá, miércoles 6 de junio de 1877. D.O.n..$^{\circ}$ 3.952. Ley de Amnistía. El 6 de junio de 1877 se promulgó la Ley 62 sobre amnistía. Esta pretendió conceder amnistía e indulto a todos aquellos que hubiesen participado en las guerras civiles y se hubieren rebelado contra el orden constitucional establecido desde julio de 1876, época en la que inició formalmente la guerra en Cauca para luego expandirse por gran parte del país. La ley estipuló una amnistía para aquellos que hubiesen cometido delitos políticos en el territorio nacional. Por otro lado, esta ley dispuso un amplio régimen de excepciones, con las personas a las cuales no conceder la mencionada amnistía y con los hechos exceptuados por la misma, que eran aquellos constitutivos de atentados revolucionarios que contrariaran el derecho de la guerra o de gentes. Lo anterior significó que las leyes de amnistía con las cuales se podían terminar las guerras civiles y las contiendas armadas no podían contrariar el derecho de gentes. Veamos tan importante ley:

LEI 62 DE 1877

(4 DE JUNIO)

Sobre amnistía

El Congreso de los Estados Unidos de Colombia 
Visto el artículo 4. ${ }^{\circ}$ de la capitulación ajustada en Manizales el día seis de abril último entre el ciudadano Jeneral Julián Trujillo, Jeneral en Jefe del Ejército del Sur, i el señor Silverio Arango, Presidente del Estado soberano de Antioquia, que hacía la guerra al gobierno Jeneral; I siendo de notoria conveniencia la espedicion de un acto de olvido que abrace a todos los comprometidos en la presente contienda, devuelva el reposo a la sociedad i haga cesar cuanto antes los males de la guerra,

DECRETA:

Art. 1. Concédase amnistía a los colombianos que hayan cometido delitos políticos en el territorio de los Estados Unidos de Colombia desde el doce de julio de mil ochocientos setenta i seis, i se les releva en consecuencia, de la responsabilidad penal en que por razón de tales delitos, hayan incurrido. Esceptuándose de esta gracia en cuanto a la responsabilidad, que por la ejecución de dichos delitos les puede corresponder:

1. Los señores Manuel Canuto Restrepo, Cárlos Bermúdez, Ignacio Montoya i Joaquín Guillermo González. Obispos respectivamente de Pasto, Popayán, Medellín i Antioquia.

2. Los Ministros del clero superior e inferior que hayan tomado armas, ya en cuerpo de ejército regular, ya en guerrillas, contra el orden constitucional, o que hayan promovido o encabezado movimientos revolucionarios contra las autoridades federales o de los Estados;

3. Los Jefes i Oficiales, que estando en servicio del Gobierno federal, se hubiesen pasado al enemigo;

4. Los Jefes o cabecillas de guerrillas o partidas armadas que, por las escesivas depredaciones que hayan cometido u ordenado, por su ferocidad notoria, o por sus malos precedentes, juzgue el Poder Ejecutivo que deben ser esceptuados de la clemencia del gobierno;

5. Los individuos que, habiéndose presentado a las autoridades lejítimas, o habiendo sido hechos prisioneros, recibieron pasaporte de dichas autoridades bajo la condición i promesa de no volver a tomar parte en la guerra, i faltaron después a su palabra, volviendo a hacer armas contra las autoridades constitucionales; i

6. Los que manteniéndose aun en armas, no las depongan dentro del término que señale el Poder Ejecutivo Nacional para cada Estado respectivamente, i en poder de las autoridades que aquel designe.

Art. 2. En la presente amnistía no se comprenden los delitos comunes que, fuera de los actos de lejítima belijerancia, conforme al derecho de la guerra, hayan cometido los revolucionarios contra la vida, la seguridad personal i la propiedad 
de los ciudadanos, los cuales delitos quedan sujetos a ser perseguidos i castigados de oficio o a solicitud de parte conforme a las leyes.

Quedan igualmente esceptuados los atentados que los revolucionarios hayan cometido contra las personas i las propiedades de los estranjeros, a quienes se deja su derecho a salvo para perseguir por los trámites legales a los autores de tales delitos.

Art. 3. Los individuos esceptuados de esta amnistía conforme al artículo $1 .^{\circ}$, que no estén acusados de delitos comunes, quedarán comprendidos en ella, siempre que acepten la condición de salir del territorio de la República i permanecer fuera de ella por un término de dos a diez años a juicio del Poder Ejecutivo.

Los que no acepten la condición de que trata este artículo, quedan sometidas a las disposiciones respectivas del Código Penal "sobre delitos contra el orden público", i las ordenanzas militares que se encuentren en el caso $3 .^{\circ}$ del art. $2^{\circ}$.

Dada en Bogotá, a veintiocho de mayo de mil ochocientos setenta i siete.

D. Declarar enemigos de la República a todos aquellos que cometieran actos en contra de la paz y la tranquilidad de la misma. Por ende, se les aplicaba el derecho de la guerra o de gentes.

17. Bogotá, viernes 20 de agosto de 1875. D.O. n. 3.528. Resolución sobre orden público. Después de los sucesos que habían alterado el orden público en los Estados de Panamá y Bolívar, ya que un grupo de rebeldes armados se había opuesto al orden constitucional vigente en ellos, se declaró turbado el orden público el 7 de agosto de 1875 en toda la Nación. El respectivo decreto ordenaba adoptar todas las medidas necesarias para el restablecimiento del orden. De esa forma, mediante la resolución de orden público que contiene el Diario Oficial en cita, se advirtió a todas las personas que cometieran cualquier tipo de actos en contra de la tranquilidad y de la paz, que serían declaradas enemigos de la República y, por ende, que se les aplicaría el derecho de la guerra. Lo anterior quiere decir que el gobierno advirtió que aplicaría el derecho de gentes a todos aquellos que le hicieran la guerra a la República. Allí se dijo:

Todos aquellos que de obra o de palabra, por medio de la imprenta o de cualquiera otro modo conciten a la rebelión, irrespeten a las autoridades federales o del Estado, o en tumultos o juntas sediciosas promuevan o fomenten la insurrección, divulguen noticias alarmantes i turben la tranquilidad pública, serán considerados como enemigos del Gobierno i tratados como tales con todo el rigor que permita el derecho de la guerra. (...) 
E. Aumentar el pie de fuerza de las tropas nacionales al necesario para tiempos de guerra. En la mayoría de decretos que declaraban turbado el orden público, se ordenaba a su vez aumentar el pie de fuerza (ej., D.O. n. ${ }^{\circ} 3.818$ de 1876). Por eso, cuando se restablecía el orden público, se ordenaba su reducción inmediata (ej., D.O. n. 3.585 de 1875).

18. Bogotá, jueves 17 de agosto de 1876.D.O.n. ${ }^{\circ} 3.818$. Declaratoria de turbación del orden público federal. En este Diario Oficial se encuentra el Decreto de Orden Público que en su artículo $1 .^{\circ}$ declaró turbado el mismo en todo el territorio nacional, esto más de un mes después de haberse declarado turbado el orden público en el Estado de Cauca. Sus fundamentos reposaron sobre los acontecimientos ocurridos en ese Estado, pero a su vez, en los del Tolima y Antioquia. En ellos también se habían levantado ejércitos rebeldes conservadores en contra del orden constitucional establecido y los mismos habían apoyado la revolución iniciada en el Cauca.

En el artículo 2. ${ }^{\circ}$ de dicho decreto se estableció que para restablecer el orden público debía aumentarse el pie de fuerza.

Cabe mencionar que cuando se declaraba turbado el orden público federal era deber de todos los Estados de la Unión hacer lo mismo, esto en virtud de la Ley del 13 de agosto de 1863 cuyo artículo 1. o prescribía: "Es deber de los presidentes de los Estados Federales declarar la situación de guerra cuando el Gobierno General haya declarado el país en dicha situación".

19. Bogotá, jueves 11 de noviembre de 1875. D.O. n..$^{\circ}$ 3.585. Decreto de restablecimiento del orden público federal. Después de haber declarado turbado el orden público federal el 7 de agosto de 1875, el Presidente de la Unión ordenó su restablecimiento, esto debido a que no había más motivos para mantener vigente la declaratoria de turbación. En ese sentido, también ordenó reducir el pie de fuerza. De esta forma, se aprecia que el Presidente no se extralimitó en el uso de las potestades excepcionales que podían ser utilizadas mientras estaba declarado turbado el orden público o el estado de guerra con el fin de restablecer el orden. Muestra de ello es que no se dejó declarada de forma indefinida la situación de anomalía (perturbación del orden o guerra), sino que por el contrario, cuando existieron motivos para considerar restablecido el orden, así se declaró. Expresó en su artículo único del Decreto de Orden Público del 11 de noviembre de 1875:

Declárese restablecido el orden público federal; i en consecuencia sin efecto alguno en lo sucesivo el decreto ejecutivo de 7 de agosto último, la resolución de 17 de los mismos sobre orden público, $i$ todas las demás disposiciones relacionadas con la situación de guerra. La fuerza pública al servicio de la Unión será reducida al pié que las leyes permiten en tiempo de paz.

F. Exigir contribuciones de guerra para el financiamiento de la misma. También, declarar y juzgar como desertores a quienes se opusieran a las medidas 
adoptadas bajo el estado de guerra o de perturbación del orden público. Además de lo anterior, también debían pagarse multas cuantiosas.

20. Consultar el ya citado Diario Oficial n. ${ }^{\circ} 3.818$ del 17 de agosto de 1876 .

21. Bogotá, jueves 24 de agosto de 1876. D.O. n..$^{\circ}$ 3.828. Declaratoria de la situación o estado de guerra en Antioquia. Tras extenderse el conflicto armado y la revolución del Estado de Cauca al de Antioquia, su presidente decidió declarar turbado el orden público y aplicar el artículo 91 de la Constitución Nacional que se refería al derecho de gentes, por ser este de aplicación necesaria en las guerras civiles y conflictos armados. Lo anterior también en cumplimiento de la ya citada Ley del 13 de agosto de 1863 .

Con base en esa situación excepcional se decretó llamar a las armas a todas las personas entre 16 y 60 años que pudieran empuñarlas. Por otro lado, se restringió la libre locomoción y se prohibió salir del Estado a no ser con un permiso especial. A su vez, se dispuso que todos aquellos que se opusieran a esas medidas pagarían multas cuantiosas y serían juzgados como desertores. Veamos el decreto:

\section{El Presidente del Estado Soberano de Antioquia Considerando:}

Que el Gobierno ha recibido aviso de que fuerzas nacionales se dirijen por la vía de Honda sobre la frontera del Sur, con el fin de atacar los Estados de Antioquia i Tolima i de intervenir en la lucha doméstica que se ventila en el

Cauca,

DECRETA:

Art. 1. Declárese el Estado de Antioquia en situación de guerra.

Art. 2. A virtud de la declaratoria a que se refiere el anterior artículo, declárese de aplicación preferente a toda disposición legal, el derecho de Jentes, de conformidad con lo dispuesto por el artículo 91 de la Constitución Nacional.

Art. 3. Queda prohibida desde luego toda comunicación con el territorio ocupado por las fuerzas que por vía de Honda, se dirijen contra el Estado; i en jeneral, con el territorio del Estado; i en jeneral, con el territorio dominado por el enemigo.

Art. 4. Queda igualmente prohibido el salir del territorio del Estado sin el correspondiente pasaporte espedido por el Poder Ejecutivo.

Art. 5. Todo individuo de la edad de diez i seis a la de sesenta años, que se encuentre en capacidad de tomar las armas queda llamado como miliciano al servicio activo, i deberá presentarse inmediatamente a la primera autoridad política del Distrito en que resida, a fin de que se le señale la División a que debe incorporarse. 
Art. 6. Los individuos que contravinieren a lo dispuesto en el artículo anterior, incurrirán en una multa de diez pesos por cada día que transcurra sin haberse presentado, i si la falta pasare de tres días, serán juzgados i condenados como desertores.

Art. 7. Procédase a prestar a los Estados del Tolima i Cauca el ausilio en guarda de su soberanía, de que trata el artículo $2 .^{\circ}$ de la Constitución Nacional, i escítese a los demás Estados de la Unión a fin de que adopten idéntica medida.

Dado en Medellín el 8 de agosto de 1876.

22. Bogotá, miércoles 2 de julio de 1879.D.O.n. ${ }^{\circ}$ 4.452. Declaratoria de peligro del orden público en el Estado del Tolima. Por el temor de que estallara una revolución en el Estado del Tolima, este decidió declarar en peligro el orden público. Lo anterior por cuanto se tenía conocimiento de que desde hacía ya varios meses en la ciudad de Bogotá se preparaba una revolución contra este Estado.

DECRETO NÚMERO 322

Por el cual se declara en peligro el orden público en el Estado

El Presidente del Estado soberano del Tolima

CONSIDERANDO:

1. Que es un hecho indudable que en la ciudad de Bogotá, se trama una revolución contra el orden público de este Estado;

2. Que por conductos fidedignos se sabe que varias partidas de jente armada han pasado ya de aquel a este Estado con el objeto de verificar el movimiento;

3. Que las cartas de los señores Didacio B. Delgado i Severiano Buendía, Jefes de la revolución, indican que esta se llevará a cabo inmediatamente;

4. Que el primero de estos Jefes partió ya de Bogotá con tal objeto.

\section{DECRETA}

Art. 1. Declárese en peligro el orden público en el Estado.

Art. 2. Para subvenir a los gastos que la situación demande, se recaudará en el Estado una contribución igual al impuesto directo del presente año. La primera mitad de esta contribución se recaudará inmediatamente i la segunda cuando lo disponga el poder ejecutivo. 
Art. 3. Desde el momento en que aparezca en el Estado la perturbación del orden, se cobrará, además, un impuesto de cuatro pesos por cada cabeza de ganado mayor que se mate para el consumo.

Art. 4. Los Recaudadores de Hacienda procederán a recaudar la contribución de que habla el artículo 2. ${ }^{\circ}$ ejecutivamente i sin dar lugar a indebidas demoras.

Dado en Neiva, a 12 de Julio de 1879.

Ignacio Manrique

G. Poner en vigencia la ley marcial, es decir, suspender la justicia civil y administrativa, por la entrada en vigor de la militar.

23. Bogotá, sábado 31 de enero de 1885. D.O. n. ${ }^{\circ}$ 6.299. Decreto de ley marcial en el Estado del Tolima. Desde finales de 1884, y hasta agosto de 1885, ciertos Estados de la Unión, como Tolima, Santander, Antioquia, Cauca y Panamá, habían empezado a rebelarse armadamente contra el Gobierno de Núñez. Principalmente, criticaban sus políticas centralistas en el marco de su proyecto de "La Regeneración".

Para esta ocasión, tras unos disturbios armados en el Estado del Tolima, el Presidente de la Unión declaró la vigencia de la ley marcial. Según él, esta era necesaria para restablecer el orden público en ese Estado. Lo anterior significó la suspensión de la justicia civil y administrativa y la entrada en vigencia de la justicia militar. A su vez, en el decreto se hace importante mención al derecho de gentes como herramienta necesaria para el restablecimiento del orden público y de la paz, y en virtud del mismo se adoptaron las medidas señaladas. Este constituyó un antecedente importante de cómo los militares, ante una alteración del orden público, podían tener la facultad para juzgar civiles y decidir sobre cualquier situación, convertiéndose en la máxima autoridad y ejerciendo un control amplio e ilimitado. Dispuso el decreto:

DECRETO

por el cual se promulga en el Estado del Tolima la ley marcial Manuel Casabianca, General en Jefe del ejército pacificador del Tolima En nombre del Poder Ejecutivo nacional y en virtud de la autodeterminación que de él ha recibido;

Teniendo en consideración:

Que el Gobierno del Estado del Tolima se ha rebelado contra la autoridad federal $\mathrm{y}$, en consecuencia, ha sido ocupado militarmente el territorio del Estado por fuerzas federales para restablecer el régimen constitucional; 
Que está ocupado el Departamento del Centro y gran parte de los pueblos del sur han desconocido la autoridad rebelde y se han puesto en armas para defender la autoridad nacional; $\mathrm{y}$

Que en los casos de guerra civil debe regir el Derecho de Gentes y las autoridades militares someterse a las disposiciones consignadas en la Parte II, títulos $1 .^{\circ}, 2 .^{\circ}$, 3. $.^{\circ} 4 .^{\circ}$ y $5 .^{\circ}$ del Código Militar,

DECRETA:

Art. 1. Declárese en vigencia en el Estado del Tolima la ley marcial. En consecuencia, cesan en el territorio del Tolima las autoridades civiles y judiciales y el Estado se administrará militarmente.

Art. 2. En los pueblos sometidos a la autoridad federal, continuará aplicándose la legislación civil y penal del Estado, en cuanto esta no contraríe providencia de carácter militar de las fuerzas al servicio de la Unión.

Art. 3. La autoridad militar asegura a los habitantes pacíficos el respeto a sus personas y sus bienes y considerará como actos de alta traición los de hostilidad a la entidad federal, cometidos por los habitantes del territorio ocupado por la fuerza nacional. Tales actos se castigarán conforme a las disposiciones del art. 1.116 del Código Militar.

Art. 4. En virtud de las autorizaciones conferidas por el artículo 1.254 del Código Militar, el General en Jefe del Ejército nacional en operaciones en el Estado del Tolima se reserva el derecho de decretar, en los casos imprevistos que ocurran y bajo su responsabilidad, las providencias y las penas que las circunstancias hagan necesarias.

Art. 5. Mientras se establece el Gobierno civil, los Alcaldes militares de los distritos ejercerán también las funciones de Jueces y administrarán justicia conforme a las leyes que han regido hasta el presente en el Estado del Tolima.

Art. 6. La autoridad militar castigará severamente todo acto violento que se cometa contra las personas o propiedades de los habitantes del Estado. Sólo las autoridades militares podrán reducir a prisión o castigar a los individuos, imponer contribuciones y hacer expropiaciones.

Art. 7. todos los actos de hostilidad ejecutados contra el Gobierno Nacional serán castigados conforme a las disposiciones del Libro III del Código Militar.

Art. 8. El presente decreto se publicará por bando en todos los distritos del Estado, se fijará en carteles en lugares públicos, y se comunicará al Gobierno nacional para sus efectos y su inserción en el Diario Oficial. 
Dado en el Cuartel General de Potrerillo, a 27 de Enero de 1885.

El General en Jefe, Manuel Casabianca.

\section{REFLEXIONES FINALES}

Existió una importante y amplia aplicación del derecho de gentes durante los conflictos armados de la segunda mitad del siglo XIX en los Estados Unidos de Colombia. Lo anterior se llevó a la práctica por medio de las figuras excepcionales de "declaratoria de turbado el orden público" y "estado de guerra". Se pudo constatar que cuando operaban estas declaratorias, el Gobierno de la Unión o el de cada Estado en particular, dependiendo de quién lo había declarado, tenía todas facultades necesarias para enfrentar las causas que ocasionaban esa perturbación del orden o guerra y, a su vez, para impedir su prolongación. Esto último por tratarse de una situación excepcional. También, que dichas facultades se fundamentaban en ciertas disposiciones de la Constitución y la ley, pero que estas no eran absolutas, pues encontraban sus límites precisamente en la propia Constitución, en las leyes y en la doctrina del derecho de gentes que hacía parte de la legislación nacional.

Asimismo, creemos que a pesar de no estar declarado turbado el orden público o en vigencia el estado de guerra, esto no significaba que el derecho de gentes dejara de aplicarse. Los Diarios Oficiales denotan que cuando hubo ataques armados inesperados o toma de plazas públicas por sorpresa, las instituciones de este derecho fueron respetadas por los combatientes así no estuviesen operando las anteriores figuras excepcionales ${ }^{19}$. Situación distinta es que en los anteriores casos pudiera firmarse un tratado de paz u otorgarse una amnistía e indulto. Aquí sí que era necesario estar regidos por un régimen excepcional y, en virtud del derecho de gentes, las disposiciones constitucionales y legales, celebrar los respectivos tratados o conceder las respectivas amnistías.

Por otra parte, en los mencionados Diarios Oficiales consultados y seleccionados por su relación con la aplicación del derecho de gentes, se encontraron una serie de medidas excepcionales que demuestran la aplicación de este derecho como una verdadera herramienta constitucional para dar solución a los conflictos armados entre 1863 y 1886. Ellas pretendieron restablecer el orden público turbado en la Nación o en los Estados, hacer la paz cuando se estaba en guerra y humanizar los mismos conflictos armados. Lo anterior pudo concretarse en la exigencia de contribuciones de guerra para el financiamiento de la misma. También, en declarar y juzgar como desertores a quienes se opusieran

19 A manera de ilustración, lo anterior puede observarse en los siguientes Diarios Oficiales: 15 de $1864,405,457$ y 460 de $1865,1.023$ y 1.041 de 1867. 
a las medidas tomadas bajo el estado de guerra o de perturbación del orden público. Así como en imponerles cuantiosas multas.

De igual modo, se tradujo en la adopción de la ley marcial, el aumento del pie de fuerza de las tropas nacionales, la declaratoria como enemigos de la República de quienes cometieran actos en contra de la paz y la tranquilidad de la misma, y el otorgamiento de amnistías e indultos para los rebeldes alzados en armas por los delitos políticos cometidos.

Resultó sumamente importante la realización de negociaciones de paz con los beligerantes que hacían la guerra. Esto llevó a la posterior celebración de tratados y acuerdos de paz entre los rebeldes y el Gobierno de la Unión o el de los Estados.

Por último, es preciso referirse a la limitación de las garantías individuales que establecía el artículo 15 constitucional. Como ya se explicó, era la misma Constitución la que permitía dichas limitaciones en tiempos de guerra o ante graves motivos de necesidad pública y de orden público. Lo anterior se concretó fundamentalmente en reclutar forzosamente para el ejército nacional a todas las personas entre 16 y 60 años que pudiesen empuñar las armas, decretar expropiaciones de armas pertenecientes a los ciudadanos, restringir la libre locomoción en determinados Estados que eran teatro de operaciones militares, prohibir manifestaciones políticas en las calles y adelantar expropiaciones a inmuebles rurales y urbanos sin indemnización previa.

Las medidas descritas se fundamentaban principalmente en los artículos $8,13,15,26,66$ y 91 constitucionales, en el artículo $1 .^{\circ}$ de la Ley del 13 de 1863 y en el libro IV del Código Militar de 1881 cuando lo hacía el Presidente de la Unión, y cuando lo hacía el de cada Estado, en las normas de sus propias constituciones, en especial la disposición que regulaba el derecho de gentes.

\section{BIBLIOGRAFÍA}

\section{Constituciones}

Constitución Política de Colombia de 1991.

Constitución de los Estados Unidos de Colombia de 1863.

\section{Doctrina}

Barbosa, Francisco. Del Derecho de Gentes al Derecho Internacional Humanitario en Colombia, 1821-1995: debate sobre una idea constitucional. Bogotá, Instituto de Estudios Constitucionales Carlos Restrepo Piedrahita, 2013. 
Camacho Roldán, Salvador. Memorias de Salvador Camacho Roldán. Bogotá, Bedout, 1923.

Restrepo Piedrahita, Carlos. Documentos para la historia del constitucionalismo colombiano No. 4. Bogotá, Universidad Externado de Colombia, 2003.

Restrepo Piedrahita, Carlos. Constituciones de la Primera República Liberal.1855-1885, t. III, Constituciones Federales Antioquia-Bolivar. Bogotá, Universidad Externado de Colombia, 1985.

Rivadeneira, Antonio José. Historia Constitucional de Colombia 1510-1978, Bogotá, Editorial Horizontes, 1978.

Valencia Villa, Alejandro. La humanización de la guerra: derecho internacional humanitario y conflicto armado en Colombia. Bogotá, Tercer Mundo Editores, 1991.

\section{Webgrafía}

Biblioteca Luis Ángel Arango y su red de bibliotecas. Guerra civil de 1876: http://www. banrepcultural.org/blaa/archivos/guerra-civil-1876

\section{Diarios Oficiales}

No. 145 de 1864, No. 149 de 1864, No. 1 de 1864, No. 37 de 1864, No. 507 de 1865, No. 1.009 de 1867, No. 3.560 de 1875, No. 3.867 de 1877, No. 3.889 de 1877, No. 4.452 de 1879, No. 212 de 1865, No. 483 de 1865, No. 532 de 1866, No. 550 de 1866, No. 2.740 de 1873 , No. 3.952 de 1877, No. 3.528 de 1875, No. 3.818 de 1876, No. 3.585 de 1875, No. 3.818 de 1876 , No. 3.828 de 1876 . 